\title{
Interpretation of data on pesticide residues in surface water in France, by grouping data within homogeneous spatial units
}

\author{
C. Gauroy ${ }^{(1)}$, N. Carluer ${ }^{(1)}$ \\ Received August 17, 2010 / Reçu le 17 août 2010 \\ Revised December 13, 2010 / Révisé le 13 décembre 2010 \\ Accepted December 13, 2010 / Accepté le 13 décembre 2010
}

\section{Key-words: water contamination, pesticide, stream, data interpretation, analysis}

\section{ABSTRACT}

In France, the SOeS^ manages a database which contains more than eight million analyses of pesticide concentrations in surface water. In order to interpret these analyses better, we tested methods based on a geographic grouping of data within homogeneous units, the hydro-ecoregions (HER). Our objectives were to find suitable descriptors and methods, and test them in order to describe the contamination and highlight explanatory factors.

In the case of the examples studied, calculating the 90th percentile of analysis results for each 15-day period allowed us to identify the seasonal and inter-annual contamination patterns associated with the analytes. We observed differences between regions and years, which are consistent with the agricultural use of pesticides (application period and registration). Moreover, differences in contamination levels between areas and products can be partly explained by the type of crop on which the products are applied.

\section{RÉSUMÉ}

Interprétation des données d'analyse de la présence de résidus de produits phytosanitaires dans les eaux de surface en France, par regroupement des données au sein d'entités géographiques

Mots-clés : contamination de l'eau, pesticide, courant, interprétation de données, analyse
La base de données gérée par le SOeS* sur les pesticides dans les eaux de surface en France contient plus de huit millions d'analyses. Pour interpréter de manière plus approfondie ces données, des méthodes ont été testées en se basant sur un regroupement géographique des données au sein d'entités homogènes (hydroécorégions de niveau 1). Les objectifs étaient de trouver des descripteurs et des méthodes adaptées et de tester leur pertinence afin de décrire la contamination et mettre en évidence les facteurs explicatifs.

En utilisant le $90^{e}$ centile des résultats d'analyse par période de 15 jours, nous avons identifié des dynamiques de contamination pour les molécules étudiées (évolution saisonnière et inter-annuelle). Les différences observées entre les régions et entre les années sont cohérentes avec l'utilisation des pesticides (périodes d'application et réglementation). De plus, les différences de niveaux de contamination entre régions et molécules sont explicables en partie par les cultures cibles des produits.

(1) Cemagref, Freshwater systems, ecology and pollution research unit, 3 bis quai Chauveau, CP 220, 69336 Lyon cedex 09, France, nadia.carluer@cemagref.fr

* Service d'observation et de statistiques of the French ministry in charge of the environment. 


\section{INTRODUCTION}

In France, monitoring of water courses and groundwater quality is a requirement in the context of the European Water Framework Directive, as well as a social requirement. This monitoring includes pesticide pollution surveillance, which is particularly necessary because contamination levels are significant (Ifen, 2007). It is carried out under multiple monitoring networks.

Each network has its own purpose (general knowledge of water quality, control of drinking water standards, or specific knowledge of pesticide contamination) and area of concern, leading to different monitoring strategies in terms of sampling date, localisation and rate. Moreover, monitoring schemes can vary according to the substances and from one year to another. Data from these networks have been centralised by the SOeS (formerly Ifen ${ }^{1}$ ) since 1997. This represents millions of data, but due to the variability in monitoring schemes, they are hard to interpret. Annual reports from the SOeS only give "an indication of the overall state and quality of water courses and of groundwater" (Ifen, 2007). Pesticide contamination in each sampling site is described by an indicator and substances are compared on the national scale. In particular, they consider that it is not possible to indicate a trend in water quality where pesticides are concerned (Ifen, 2007).

However, it would be useful to further the interpretation of available data to improve the knowledge of:

- the extent of the pesticide contamination and the exposure of aquatic organisms. This may be linked to ecotoxicological data about aquatic organisms in order to determine the impact and risk of pesticides in the environment;

- which factors influence the most pesticide transfers, in order to reduce the contamination as efficiently as possible. For example, in the United States, $48 \%$ of the amount of variance in frequencies in pesticide detection in groundwater (National Water-Quality Assessment data) was explained by estimated use and Koc (organic-carbon sorption constant) (Kolpin et al., 1998). In surface water, a study of seasonal trends showed that there is a link between the contamination level and the stream flow which occurred in the previous days (Vecchia et al., 2008);

- the contamination trend, to assess the effects of environmental policies. For example, surface water quality in the Netherlands improved with respect to pesticides between 1997-1998 and 2003-2004 (Vijver et al., 2008);

- which pesticides are most often found as pollutants and under which circumstances (postregistration monitoring).

Except for the Netherlands, we have not found such a study on a national scale in Europe (with contamination trends, comparison between regions, links with causal factors, etc.).

As a first step towards this enhanced knowledge, the objectives of this study are to further the characterisation of the contamination of water courses by pesticides (contamination levels, spatial variations, trends, seasonal fluctuations, substances involved, etc.) and to highlight the influence of the causal factors by testing a method that consists of grouping data from different monitoring sites on a geographic basis.

\section{MATERIALS AND METHODS}

\section{$>$ DATA}

We used SOeS pesticide analysis data in French water courses from 1997 to 2006. At the time we carried out this study, data after 2006 were not yet available. Each analysis is linked to a sampling location, a date and a substance. The result of the analysis is either the molecule

\footnotetext{
1 Institut français de l'environnement.
} 
concentration, the limit of detection if the molecule was not detected, or the limit of quantification if traces of the molecule were detected but not quantified. The database contained 8.6 million analyses related to 478 molecules (pesticide active substances and metabolites) and 3400 sampling locations. The product concentrations were equal to or above the limit of quantification (LOQ) in $2.8 \%$ of analyses, between the LOQ and the limit of detection (LOD) in less than $0.1 \%$ of analyses, and under the LOD in $97.1 \%$ of analyses.

Although the number of analyses keeps increasing, from 80000 in 1997 to 1.8 million in 2006, the sampling locations, sampling rates and molecules analysed may vary from one year to another (for example, one-third of the locations were sampled at least once a year for one year only, and another third for two years only out of the ten years of the study database).

These data do not include information on the flow dynamics at the time of the sampling. Some monitoring networks take the samples on a fixed date, whereas others take them after a rainy period.

To free the interpretation from the variations in monitoring schemes, we tested a method of interpretation by gathering data on a geographic basis.

\section{> GEOGRAPHIC GROUPING}

Pesticide transfers to water courses may be influenced by topography, climate, soil type, bedrock and water flow. We assumed that in an area in which these factors are quite homogeneous, pesticide transfers are similar in the whole area, and so are temporal patterns of concentration in water courses. Grouping pesticide concentration data within such an area can overcome several problems: the low number of analyses per sampling location (to study seasonal variability, for example), the change of sampling locations over the years and the uncertainties about the exact location of some sampling sites.

The hydro-ecoregions were chosen to group the data. These spatial units have been defined to implement the European Water Framework Directive, which requires a typology of aquatic ecosystems based on geographical features to define reference conditions (Wasson et al., 2002). Hydro-ecoregions (HER) are entities with homogeneous characteristics: geology (nature of rocks), topography (elevation and slopes), water network (structure and organisation) and climate (rainfall regime and maximum temperature interpreted in relation to natural vegetation). This regionalisation method is used in France, Italy and Austria, and the whole of Europe has been cut into HER ${ }^{2}$. In France, 22 level 1 HER (HER-1) were defined (Figure 1). Although HER are not defined according to the land use, they are quite coherent with it, as land use is also dependent on the climate, the geology and the topography. Figure 2 shows the agricultural orientation of French municipalities (technical and economic) ${ }^{3}$. For example, there are lots of vineyards, orchards and flowers growing in the HER 6 (Mediterranean), whereas in the HER 1 (Pyrénées) the dominant farming is ruminant husbandry.

\section{> CHOICE OF DESCRIPTORS}

The percentage of detections or quantifications of the analyses is a commonly-used descriptor. Nevertheless, the LOQ and LOD vary according to the laboratory, molecule and time, and that strongly influences this descriptor. For example, lindane (gammahexachlorocyclohexane) and terbuthylazine have similar percentages of quantifications ( $8.07 \%$ and $8.26 \%$, respectively), whereas the average concentration of lindane is $0.01 \mu \mathrm{g} \cdot \mathrm{L}^{-1}$ as opposed to $0.13 \mu \mathrm{g} \cdot \mathrm{L}^{-1}$ for terbuthylazine. This difference is due to the lower LOQs of lindane.

Instead, we used the percentage of concentrations over $0.1 \mu \mathrm{g} \cdot \mathrm{L}^{-1}$, as $97.8 \%$ of LOQs and LODs in the database are equal to or inferior to this value. Moreover, $0.1 \mu \mathrm{g} \cdot \mathrm{L}^{-1}$ is the limit

2 REBECCA project, www.environment.fi/syke/rebecca.

3 Agreste (department of statistics of the French ministry in charge of agriculture), http://agreste. agriculture.gouv.fr (Otex: Orientation technico-économique des exploitations). 


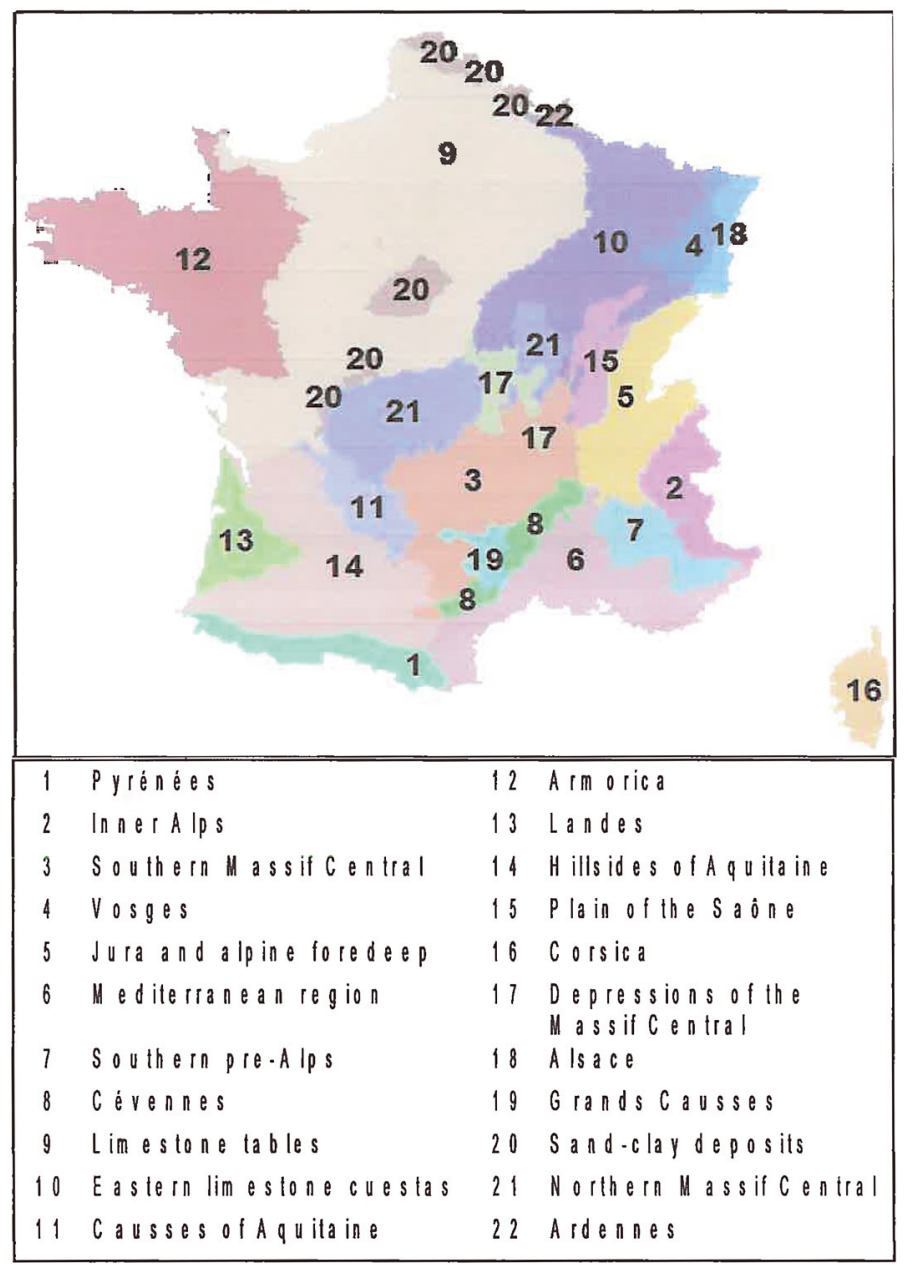

Figure 1

Map of French HER-1 (from Wasson et al., 2002).

Figure 1

Carte des HER de niveau 1 de France métropolitaine (d'après Wasson et al., 2002).

accepted in drinking water for almost all pesticides, so it is a good reference point in pollution assessment.

To study seasonal or annual variations, we tried to use statistics (percentiles) twice per month (the first 15 days and the rest of the month, thus years can be compared with each other or accumulated). We replaced LODs by 0 and LOQs by LOQ/2 in the database for this analysis.

As the whole percentage of quantifications is low, the median does not allow one to describe the contamination precisely, as we can see in the example of diuron in the HER 20 (sand-clay deposits) (Figure 3), and the maximum is not very representative of the contamination levels due to some extreme but unusual concentrations. Instead, we tested the 90th percentile and also tried to interpret the data with the 70th to 99th percentiles for some products, which led to similar results.

The percentage of concentrations above $0.1 \mu \mathrm{g} \cdot \mathrm{L}^{-1}$ and the 90 th percentile per 15 days were therefore the descriptors we used because they were convenient for our objectives. However, these might not be adequate to estimate the exposure of aquatic organisms. 


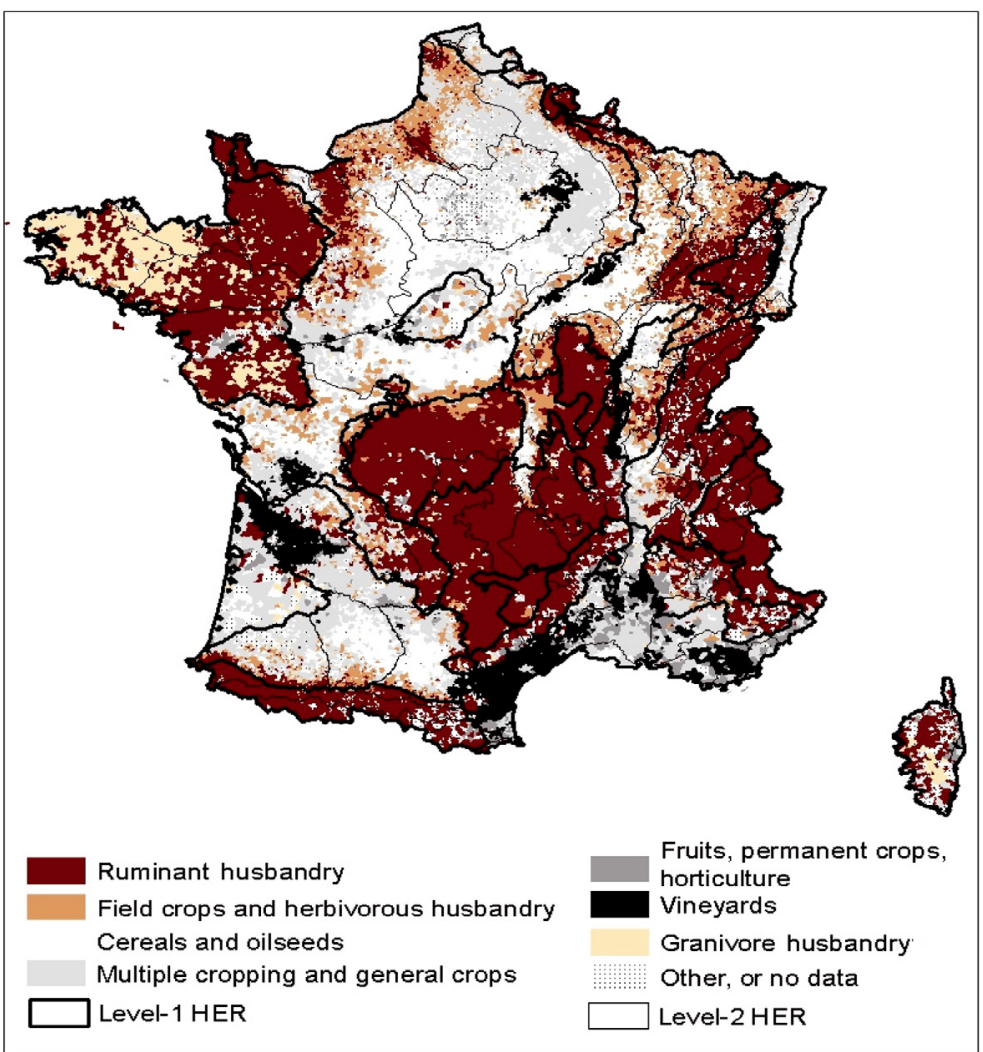

\section{Figure 2}

Map of agricultural orientation of French municipalities (technical and economic) in 2000 and levels 1 and 2 HER (from Wasson et al., 2002 and Agreste).

\section{Figure 2}

Carte des orientations technico-économiques des communes en 2000 et des HER de niveaux 1 et 2 (d'après Wasson et al., 2002 et Agreste).

\section{> PRINCIPAL COMPONENT ANALYSIS (PCA)}

First, the variations in water contamination for some substances were studied. A PCA (Bouroche and Saporta, 2002) was conducted on the percentages of the concentrations above $0.1 \mu \mathrm{g} \cdot \mathrm{L}^{-1}$ per substance (variables) and HER-1 (individuals) to compare the contamination levels between substances and HER-1. To restrict the number of variables, we considered only the 55 substances for which there were more than 10000 analyses and which have the highest percentage of concentrations above $0.1 \mu \mathrm{g} \cdot \mathrm{L}^{-1}$ on the whole.

\section{> INDICATOR FOR SUBSTANCES' TRANSFER ABILITY}

To assess the substances' transfer potential, we used the Groundwater Ubiquity Score (GUS), which is defined as GUS $=\log (\mathrm{DT} 50)(4-\log (\mathrm{Koc}))$, where DT50 is the half-life time in soil, and Koc is the organic-carbon sorption constant (Gustafson, 1989). We used the GUS values from the Footprint Pesticide Properties Database (PPDB) ${ }^{4}$. Although the GUS was originally constructed to assess soil leaching potential, we chose to evaluate its potential for transfer to streams, for lack of an adequate indicator.

\footnotetext{
4 http://sitem.herts.ac.uk/aeru/footprint/index2.htm.
} 


\section{Figure 3}

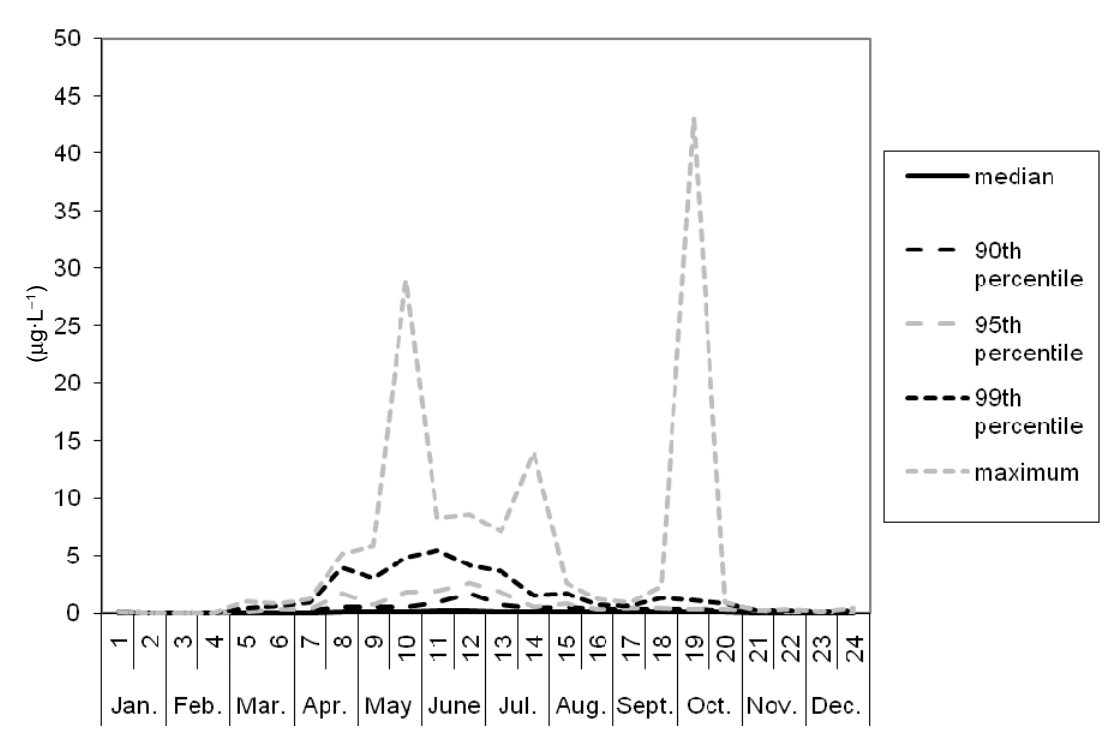

Percentiles of analysis results per 15 days, years 1997-2006 together, for diuron in the sand-clay deposits HER (20).

\section{Figure 3}

Centiles par quinzaine des résultats d'analyse du diuron, années 1997 à 2006 confondues, dans l'HER dépôts argilo-sableux (20).

\section{RESULTS}

\section{> SEASONAL VARIATIONS}

For the substances we studied as examples, the seasonal variation appears to be similar between years. Isoproturon, a herbicide mostly used for cereals, shows two periods of contamination per year (Figure 4): the first one at the end of the winter and the second one in autumn. They fit with the application periods of this pesticide: at the vegetation regrowth and at the winter cereal sowing.

\section{$>$ TRENDS}

With this way of describing seasonal variations, we can see not only similarities between years, but also differences. For example, atrazine was detected above all between May and September (Figure 5). Its contamination level decreased steadily until 2003, and sharply between 2003 and 2004. This may be due to the reduction in the amount of substance applied, as a local ban on atrazine use has been implemented since 1997, with a complete ban on sale at the end of 2002 and a complete ban on use at the end of 2003. We can see that in 2004, the contamination still followed the same pattern. As contamination increased again in May, corresponding with the application period, we can assume that some illegal applications of atrazine occurred.

\section{> SPATIAL VARIABILITY}

\section{Seasonal dynamics and spatial variability}

We can notice differences in the contamination patterns and also between the HER. For example, isoproturon (Figure 6) is detected during two annual periods, but these vary from 


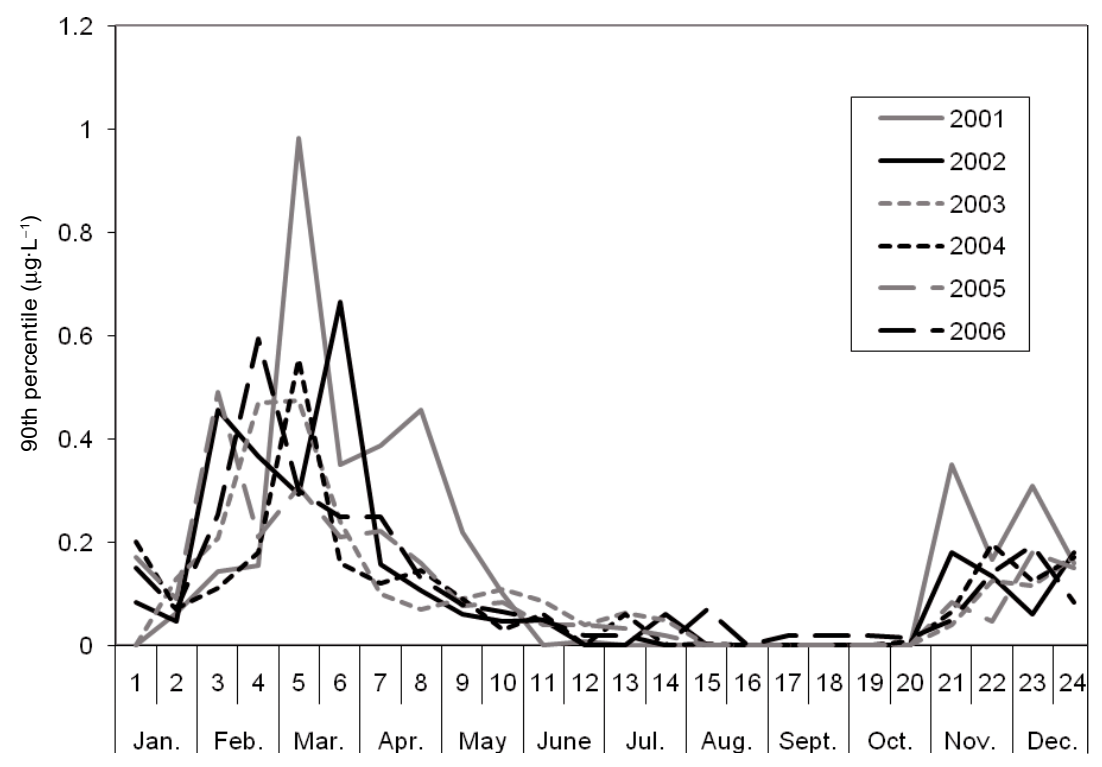

Figure 4

90th percentile of analysis results per 15 days, for isoproturon, in the Armorica HER (12).

Figure 4

$90^{\mathrm{e}}$ centile par quinzaine des résultats d'analyse de l'isoproturon dans l'HER armoricaine (12).

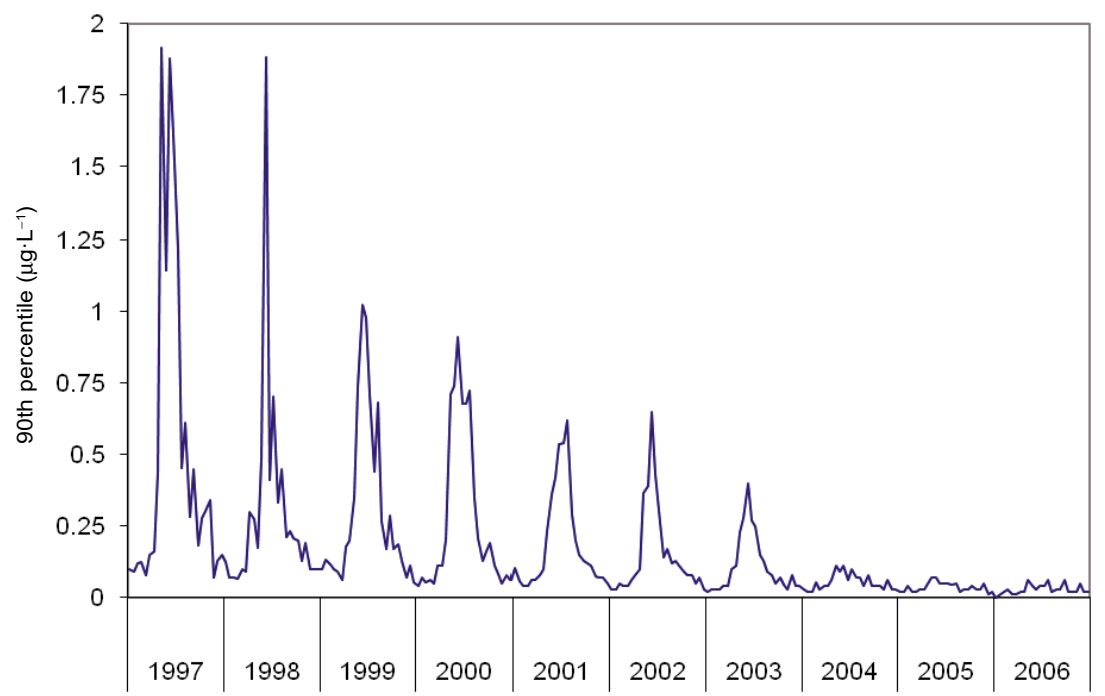

Figure 5

90th percentile of analysis results per 15 days, for atrazine in metropolitan France.

\section{Figure 5}

$90^{\mathrm{e}}$ centile par quinzaine des résultats d'analyse de l'atrazine en France métropolitaine.

West to East (from the Armorica HER 12 to the plain of the Saône HER 15 to the HER 18 of Alsace): the spring peak of contamination occurs later in the East than in the West side of the country and the autumn peak occurs earlier and is more significant in the East than in the West. Again, this fits with the corresponding application periods, as vegetation regrowth occurs later and winter cereal sowing occurs earlier in the East.

As for diuron (Figure 7), a herbicide used on vineyards, orchards and non-agricultural areas, it was detected earlier in HER where there are vineyards (the plain of the Saône HER 15, the HER 18 of Alsace and the limestone tables HER 9) than in HER where uses are not 


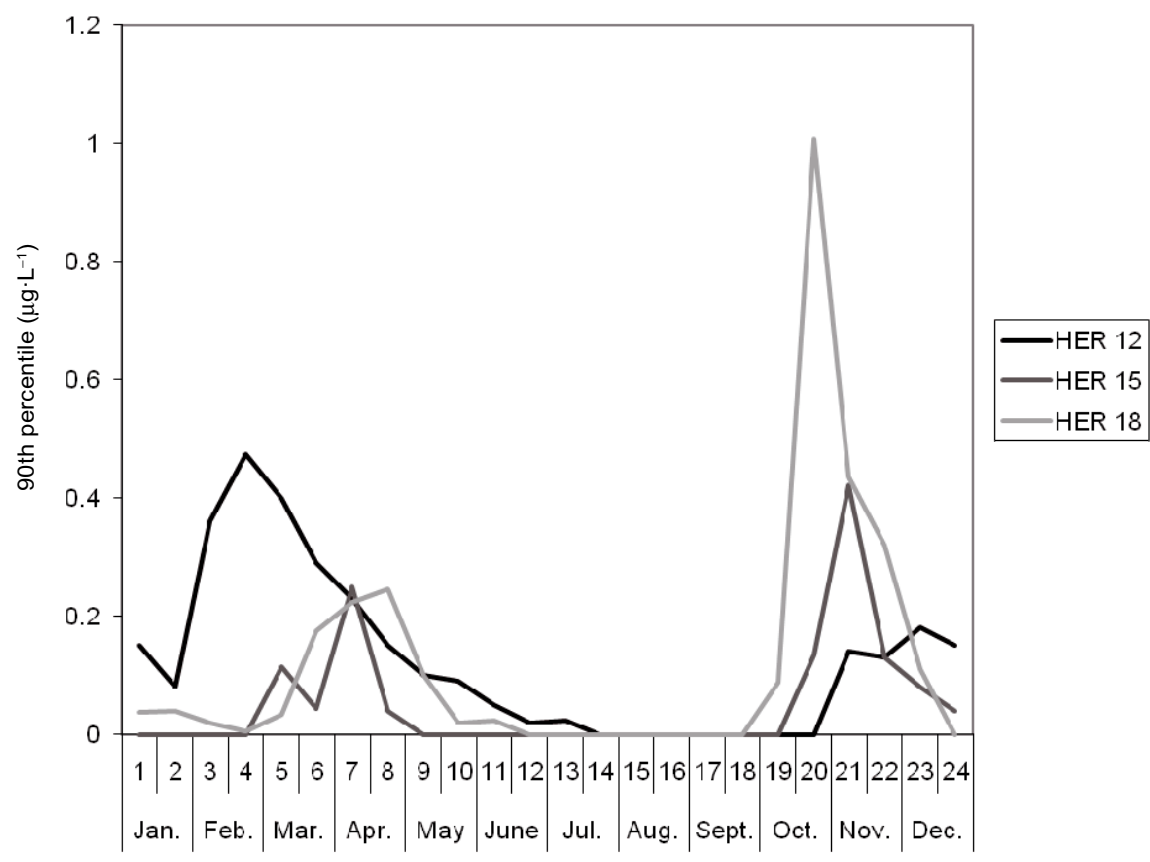

Figure 6

90th percentile of analysis results per 15 days for isoproturon, years 1997-2006 together, in the Armorica HER (12), the plain of the Saône HER (15) and the Alsace HER (18).

\section{Figure 6}

$90^{\mathrm{e}}$ centile par quinzaine des résultats d'analyse de l'isoproturon, années 1997 à 2006 confondues, dans les HER armoricaine (12), Plaine de la Saône (15) et Alsace (18).

linked to agriculture (sand-clay deposits HER 20 and the Armorica HER 12). Moreover, the contamination level is much higher in the HER 15 and 20 than in the others. This may be either because more substance is applied in these two HER or because they are more vulnerable to pesticide transfer to surface water.

\section{Spatial variability of contamination levels and product use}

The PCA results show that the first component, which carries $34 \%$ of the variance, does not differentiate the individual substances (Figure 8) but the HER according to their level of contamination (Figure 9). HER 15 (plain of the Saône), 10 (Eastern limestone cuestas), 14 (hillsides of Aquitaine), 9 (limestone tables), 20 (sand-clay deposits), 12 (Armorica) and 18 (Alsace) are the most contaminated. HER 22 (Ardennes), 17 (depressions of the Massif Central), 5 (Jura and alpine foredeep), 6 (Mediterranean) and 3 (Massif Central) are less contaminated, and HER 1 (Pyrénées), 2 (Inner Alps), 4 (Vosges), 7 (Southern pre-Alps), 8 (Cévennes), 11 (Causses of Aquitaine), 13 (Landes), 16 (Corsica), 19 (Grands Causses) and 21 (Southern Massif Central), which are regions of mountains and forests, have almost no detection of pesticides.

Thus, a large part of the variability observed depends on the regional characteristics (their vulnerability and/or the intensification of agricultural practices) and not on the substances.

The second component carries $16 \%$ of the variability and differentiates substances or metabolites of substances applied mostly on vineyards (2,6-dichlorobenzamide, norflurazon, procymidone, desethyl-terbuthylazine, azoxystrobin, terbuthylazine, oxadixyl, pyrimethanil and dimethomorph) or rapeseed (tebutam) (circle 1 in Figure 8). They are detected in HER 15 (Plain of the Saône) in higher quantities than in the other HER, more specifically in the Beaujolais area for vineyards and in the north of the HER for rapeseed. 


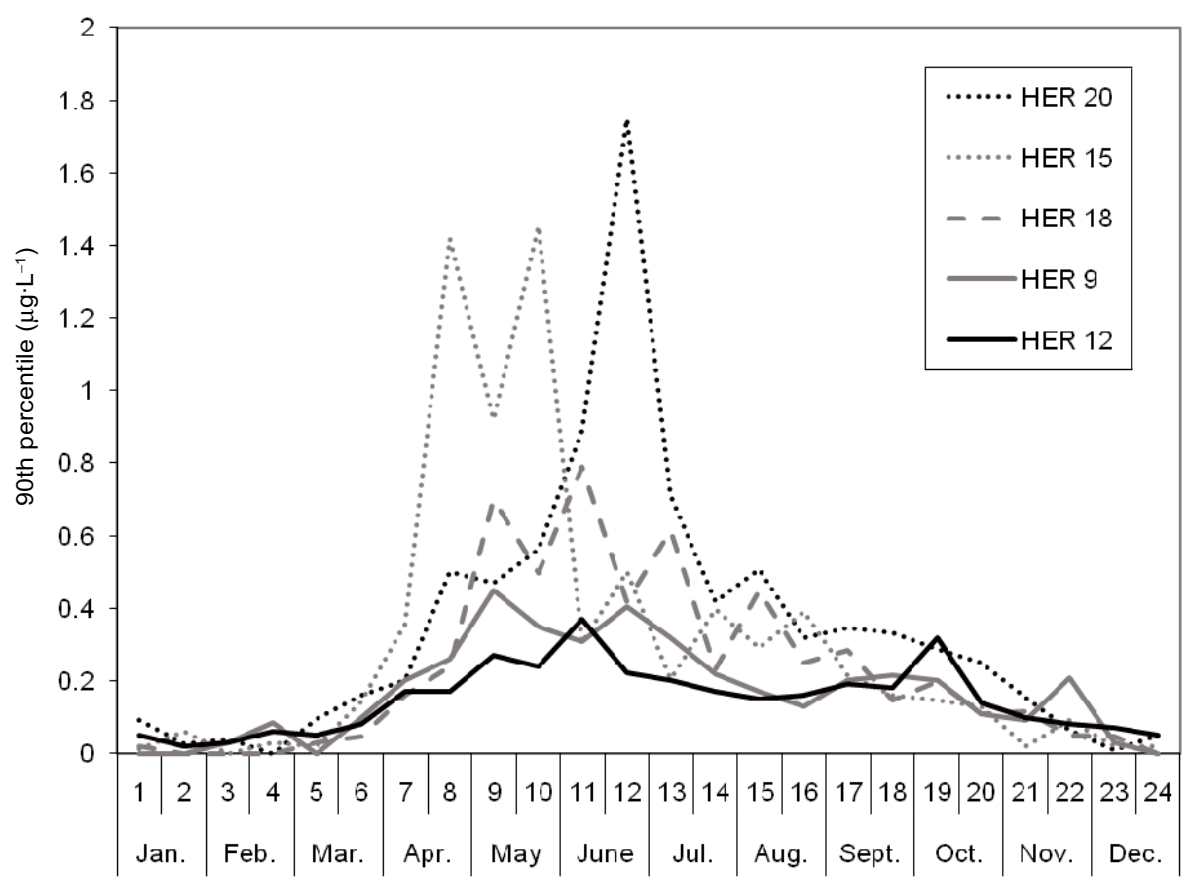

Figure 7

90th percentile of analysis results per 15 days for diuron, years 1997-2006 together, in HER 20 (sand-clay deposits), 15 (plain of the Saône), 18 (Alsace), 9 (limestone tables) and 12 (Armorica).

\section{Figure 7}

$90^{\circ}$ centile par quinzaine des résultats d'analyse du diuron, années 1997 à 2006 confondues, dans les HER armoricaine (12), plaine de la Saône (15), Alsace (18), dépôts argilo-sableux (20) et tables calcaires (9).

The third component opposes substances used among others on beets (metamitron and chloridazon) and potatoes (prosulfocarb) (circle 2 in Figure 8) in HER 20 (sand-clay deposits) and 9 (limestone tables) (Figure 9), with substances used on corn and/or sunflower (acetochlor, dimethenamid, metolachlor and alachlor) (circle 3).

A fourth group of substances can be isolated. It is composed of diuron, aminotriazole, cyprodinil, glyphosate, AMPA and isoproturon, detected significantly in HER 20, 18, 10, 12 and 9, but also in HER 15 (circle 4 in Figure 8). These products can be applied on a broad range of targets, including vineyards, non-agricultural areas and cereals. Therefore, this particular spatial distribution of contamination must be due to the vulnerability of the surface water and/or the intensification level of agricultural practices than to specific target crops.

This PCA does not highlight a specific spatial distribution of the contamination for substances applied on cereals.

\section{> CONTAMINATION LEVELS AND SUBSTANCE PROPERTIES}

We saw that a part of the variability within contamination can be explained by the type of crop on which the substances are applied. Is the residual variability linked to the substances' transfer ability? Figure 10 represents the contamination levels of the substances applied on vineyards and identified with the PCA in each of the three HER where they are the most detected, according to their GUS. There is no significant correlation between the GUS and the contamination level, either for this group of substances (group 1) or the other ones (groups 2, 3 and 4). 


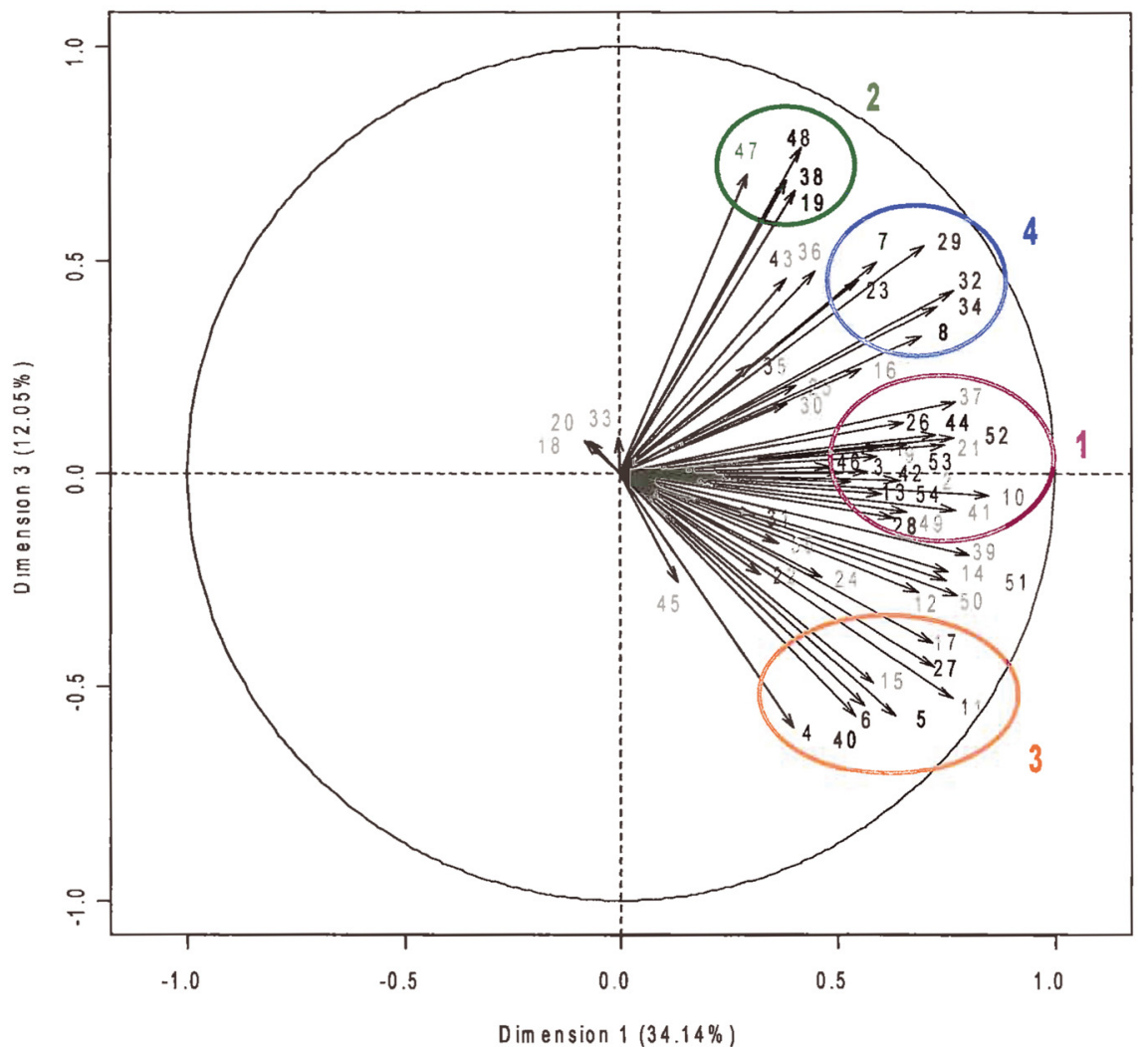

\begin{tabular}{|c|l|ll|}
\hline 1 & $2,4-D$ & 29 & Diuron \\
\hline 2 & $2,4-M C P A$ & 30 & Ethofumésate \\
\hline 3 & 2,6 -dichlorobenzamide & 31 & Flusilazole \\
\hline 4 & 2-hydroxy atrazine & 32 & Glyphosate \\
\hline 5 & Acétochlore & 33 & Hydroxyterbuthylazine \\
\hline 6 & Alachlore & 34 & Isoproturon \\
\hline 7 & Aminotriazole & 35 & Lénacile \\
\hline 8 & AMPA & 36 & Linuron \\
\hline 9 & Anthraquinone & 37 & Mécoprop \\
\hline 10 & Atrazine & 38 & Métamitrone \\
\hline 11 & Atrazine déisopropyl & 39 & Métazachlore \\
\hline 12 & Atrazine déséthyl & 40 & Métolachlore \\
\hline 13 & Azoxystrobine & 41 & Nicosulfuron \\
\hline 14 & Bentazone & 42 & Norflurazon \\
\hline 15 & Bromacil & 43 & Oxadiazon \\
\hline 16 & Carbendazime & 44 & Oxadixyl \\
\hline 17 & Carbofuran & 45 & Piperonyl butoxyde \\
\hline 18 & Chlordécone & 46 & Procymidone \\
\hline 19 & Chloridazone & 47 & Propyzamide \\
\hline 20 & Chlorprophame & 48 & Prosulfocarbe \\
\hline 21 & Chlortoluron & 49 & Pyriméthanil \\
\hline 22 & Clopyralide & 50 & Simazine \\
\hline 23 & Cyprodinil & 51 & Tébuconazole \\
\hline 24 & Dicamba & 52 & Tébutame \\
\hline 25 & Dichlorprop & 53 & Terbuthylazine \\
\hline 26 & Diflufenicanil & 54 & Terbuthylazine déséthyl \\
\hline 27 & Dimethenamide & 55 & Triclopyr \\
\hline 28 & Diméthomorphe & & \\
\hline & & & \\
\hline
\end{tabular}

Figure 8

PCA on the percentages of the concentrations above $0.1 \mu \mathrm{g} \cdot \mathrm{L}^{-1}$ per substance and HER-1: variables factor map, dimensions 1 and 3.

Figure 8

ACP des pourcentages de concentrations supérieures à $0,1 \mu \mathrm{g} \cdot \mathrm{L}^{-1}$ par molécule et par HER-1 : cercle des corrélations dans le plan formé par les première et troisième dimensions. 


\section{Individuals factor map (PCA)}

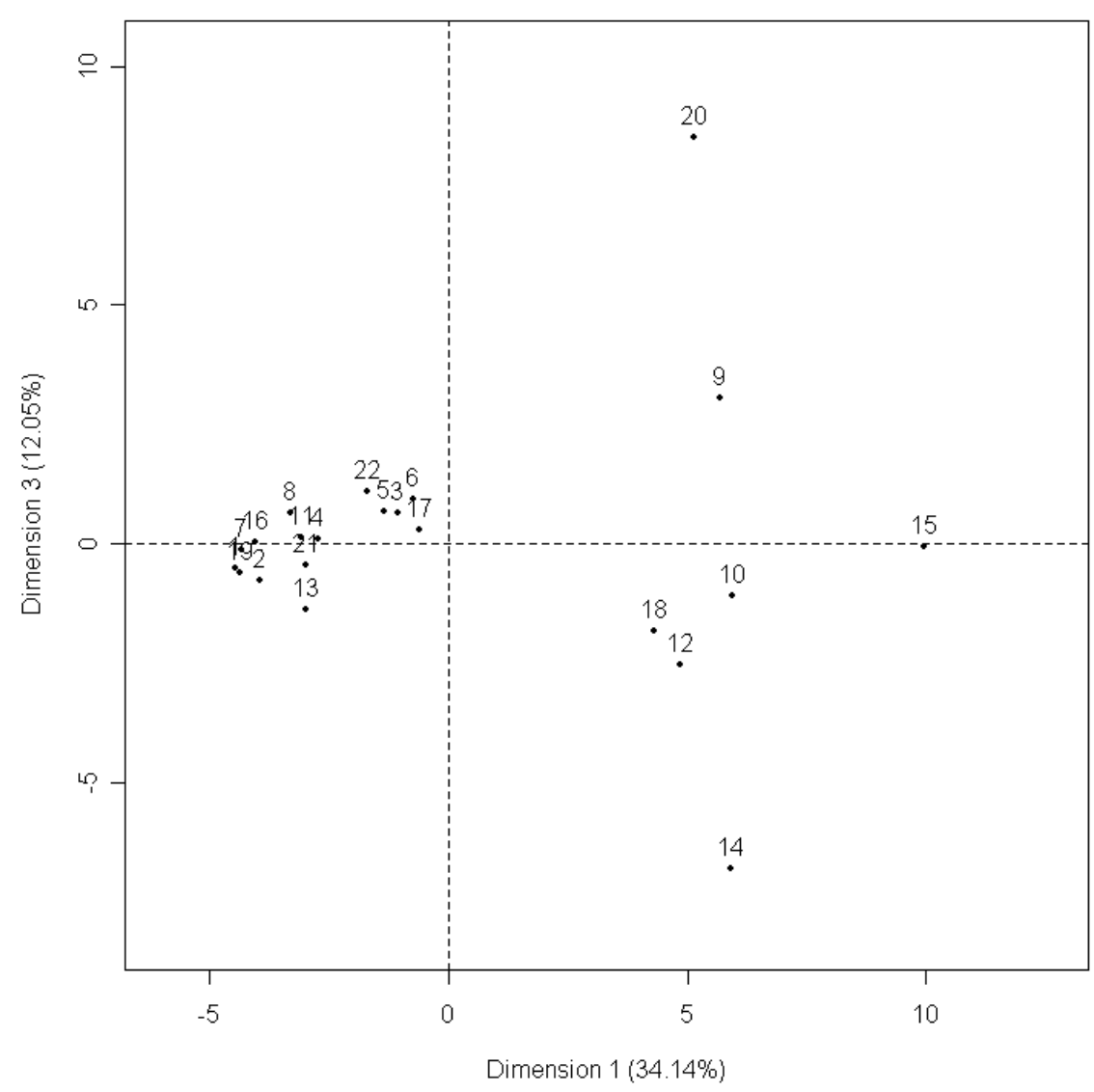

\section{Figure 9}

PCA on the percentages of the concentrations above $0.1 \mu \mathrm{g} \cdot \mathrm{L}^{-1}$ per substance and HER-1: individuals factor map, dimensions 1 and 3.

\section{Figure 9}

ACP des pourcentages de concentrations supérieures à $0,1 \mu \mathrm{g} \cdot \mathrm{L}^{-1}$ par molécule et par HER-1 : graphe des individus dans le plan formé par les première et troisième dimensions.

\section{DISCUSSION}

\section{> RELEVANCE OF THE METHOD}

\section{Extent of the contamination, exposure of aquatic organisms}

Calculating percentiles of concentrations per HER is an efficient way to describe the contamination, especially the seasonal variations. However, it provides statistics on the scale of the regions and we cannot deduce the contamination of a specific site from these results. Considering the contamination patterns would be useful to design the monitoring plan, such as optimising the place and date of samplings, target substances, etc.

\section{Trends}

This way of describing seasonal variations is interesting because it shows contamination patterns which are not always visible on the scale of a stand-alone sampling site. In particular, the effects of changes in pesticide registration (such as for atrazine) are visible. 


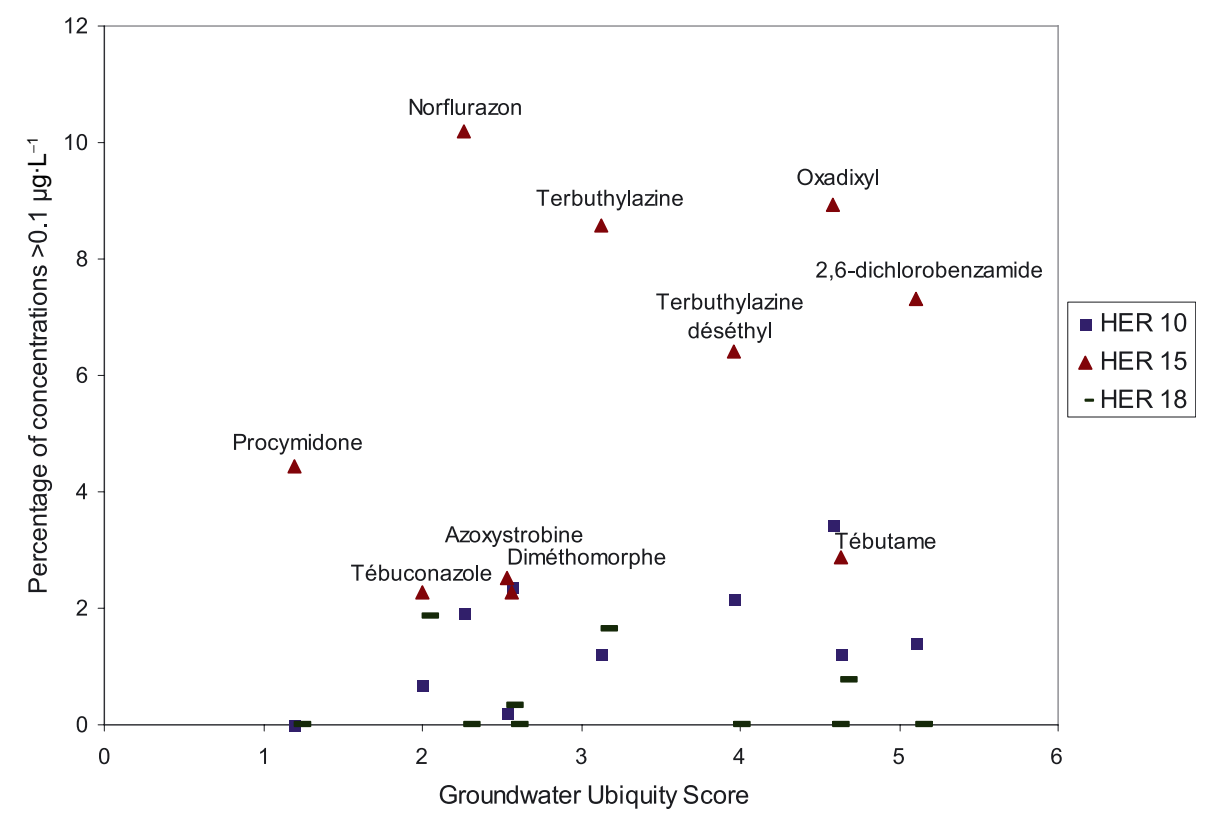

Figure 10

Percentages of the concentrations above $0.1 \mu \mathrm{g} \cdot \mathrm{L}^{-1}$ per substance and HER-1, varying with the GUS.

Figure 10

Pourcentage de concentrations supérieures à $0,1 \mu \mathrm{g} \cdot \mathrm{L}^{-1}$ par molécule et par $\mathrm{HER}-1$ en fonction de l'indice GUS des molécules.

\section{Ranking}

Using the 90th percentile or the percentage of concentrations above $0.1 \mu \mathrm{g} \cdot \mathrm{L}^{-1}$ of spatially grouped data allows one to compare substances or regions despite the differences in monitoring plans.

\section{Factors influencing the contamination}

The contamination patterns identified so far are coherent with agricultural practices (application date, substances used). This and the persistence of these patterns between years show the relevance of the method, in spite of the constraints due to the heterogeneity of the data. It also highlights the part of the factors which influence the contamination, such as plant protection product registration or climate.

The methods applied allowed the identification of spatial variation between HER. There are HER where the contamination is obviously worse and there is still work to do to explain these differences, whether due to applied quantity (larger surface of target crops or higher pest influence) or due to the vulnerability of the environment. Likewise, differences in the contamination levels between substances could not be linked to their chemical properties, either because we did not use a suitable indicator, as the GUS is designed for groundwater, or because other factors interact. For example, we lacked data on the amount of substances applied so we could not separate the influence of this factor. In addition, because we assumed it was not relevant on this scale, we did not take into account which kinds of transfer processes are dominant between the fields and the rivers.

This method of grouping data in spatial units is limited by the fact that some rivers cross the units, so contamination of the corresponding sampling sites depends on the upstream areas too. 


\section{> RELEVANCE OF HER AS SPATIAL UNITS}

In this study we assumed that HER were appropriate for our objectives, and we highlighted persistency within HER and differences between them. However, the heterogeneity of transfer patterns within a spatial unit is hidden by the descriptors we used, and at times this could be more significant than the differences between HER. To test this we tried to use other smaller spatial units. Small agricultural areas (PRA) or level 2 HER are much smaller so they sharply decrease the amount of data within each unit and so the 90th percentiles are less stable from one year to another. We also considered units made up of level 2 HER with similar flow rates (Catalogne and Sauquet, 2009) or land use (using Corine Land Cover or the agricultural orientation) but this provided the same kinds of results and we lacked the means to compare the relevance of the different units.

\section{> CONCLUSIONS AND RECOMMENDATIONS}

This method allows one to describe the contamination of surface water by pesticides, and particularly to show the regions and periods of relatively high contaminations.

Pesticide distributors have to register the amounts of pesticides they sell in France in a database, to pay a tax on non-point pollution. This database could be useful to assess the amounts of pesticides applied and to study the link between pressure and impacts.

A second interesting prospect would be to compare the contamination of groundwater and surface water. That could improve our knowledge of the environment's sensitivity to pesticide transfer.

\section{ACKNOWLEDGEMENTS}

This study was financed by the Onema. We are grateful to the SOeS for the data, to the Onema/Cemagref Laboratory of Quantitative Hydroecology for additional data, to Claire Lauvernet for her help in automating the calculations and plotting, and to Alexandra Fontaine and Rafael Muñoz-Carpena for proofreading.

\section{REFERENCES}

Bouroche J. and Saporta G., 2002. L'analyse des données, 8th edn., Presses Universitaires de France, Paris.

Catalogne C. and Sauquet E., 2009. Interpolation des courbes de débits classés, Rapport d'avancement. Convention de partenariat 2008 Onema-Cemagref.

Gustafson D.I., 1989. Groundwater ubiquity score: a simple method for assessing pesticide leachability. Environ. Toxicol. Chem., 8, 339-357.

Ifen (Institut français de l'environnement), 2007. Les pesticides dans les eaux - Données 2005, les dossiers de l'Ifen, $n^{\circ} 9$.

Kolpin D.W., Barbash J.E. and Gilliom R.J., 1998. Occurrence of pesticides in shallow groundwater of the United States: Initial results from the national water-quality assessment program. Environ. Sci. Technol., 32, 558-566.

Vecchia A., Martin J. and Gilliom R., 2008. Modeling variability and trends in pesticide concentrations in streams. J. Am. Water Resour. Assoc., 44, 1308-1324.

Vijver M., Van't Zelfde M., Tamis W., Musters K. and De Snoo G., 2008. Spatial and temporal analysis of pesticides concentrations in surface water: Pesticides atlas. J. Environ. Sci. Health B, 43, 665-674.

Wasson J., Chandesris A., Pella H. and Blanc L., 2002. Les hydro-écorégions de France métropolitaine, approche régionale de la typologie des eaux courantes et éléments pour la définition des peuplements de référence d'invertébrés. Cemagref. 